\title{
Prospek Nazhir Wakaf Global Berbasis Pesantren di Era Digital
}

\section{Nazhir Prospect of Global Waqf Based on Pesantren (Islamic Boarding Schools) in the Digital Era}

\author{
Acep Zoni Saeful Mubarok \\ Fakultas Agama Islam Universitas Siliwangi \\ Email: accefs@unsil.ac.id \\ Artikel diterima 31 Maret 2020, diseleksi 20 Mei 2020, \\ dan disetujui 5 Juli 2020
}

Abstrak: Pesantren tengah memasuki era digital yang menuntut perubahan paradigma dalam segala hal. Termasuk dalam pengelolaan wakaf secara produktif. Selama ini pesantren sudah sangat akrab dengan pengelolaan wakaf. Beberapa pesantren telah berhasil menjadikan aset wakaf pesantren sebagai wakaf produktif. Hal itu dikarenakan pesantren merupakan nazhir wakaf yang sudah berpengalaman. Berangkat dari era digital sekarang dan kebutuhan pengelolaan wakaf produktif secara global. Pesantren memiliki prospek yang tinggi untuk memperluas fungsi kenazhirannya tidak hanya lokal tapi internasional. Studi ini bertujuan untuk menelaah peluang pesantren sebagai nazhir wakaf global. Dengan menggunakan metode kualitatif yang bersumber dari kajian literatur, kemudian dianalisis bagaimana faktor pendukung yang berupa kekuatan dan peluang serta faktor penghambat berupa kelemahan. Hasil dari studi ini menunjukan ternyata pesantren sangat prospektif untuk menjadi nazhir wakaf global. Terdapat beberapa faktor pendukung yang merupakan kekuatan pesantren menuju nazhir global yaitu hadirnya era digital yang merupakan pintu masuk menuju dunia global, sebaran jumlah pesantren di Indonesia yang sangat banyak, modal pengalaman pesantren sebagai nazhir profesional yang sukses, dan sebagai lembaga pendidikan agama terpercaya. Selain itu adanya dukungan regulasi berupa Undang- 
Undang Pesantren dan perundangan tentang perwakafan. Selain faktor pendukung, pesantren juga memiliki kelemahan yang akan mereduksi program tersebut yaitu karena tidak adanya kesiapan perangkat teknologi informasi di pesantren, tapi tidak dapat digeneralisir untuk semua pesantren karena hanya terdapat di beberapa pesantren. Kelemahan tersebut pun bukan merupakan penghambat yang urgen karena dapat diperbaiki dengan literasi.

Kata Kunci: Pesantren, era digital, nazhir, wakaf, global

Abstract: Pesantren are entering the digital era that demands a paradigm shift in all aspects, including in managing the waqf productively. So far, pesantren have been very familiar with managing waqf. Some of them have succeeded in making their waqf assets productive. That is because they are experienced as nazhir waqf starting from the current digital era and the need for productive waqf management globally. Pesantren have high prospects for expanding the function of its fulfillment not only locally but internationally. This study aims at examining the opportunities of pesantren as global nazhir waqf. Qualitative methods are used in this study deriving from literature studies and analyzed how the supporting factors in the form of strengths and opportunities and inhibiting factors in the form of weaknesses. The results of this study show that pesantren are very prospective to become a global nazhir waqf. There are several supporting factors which become the strength of pesantren towards global nazhir namely the presence of the digital era which is the entrance to the global world, the distribution of the number of pesantren in Indonesia is very large, the experience as successful and professional nazhir, and as trustful religious institution.In addition, there is regulatory support in the form of the pesantren law and legislation on endowments. On the contrary, few pesantren have weaknesses that will reduce the program due tounprepared information and technology devices. However, it is not an urgent obstacle, for it can be overcome by literacy.

Keywords: Pesantren, digital era, nazhir, waqf, global 


\section{A. Pendahuluan}

Manusiasaatinitengahmemasukiduniatanpasekatdanbatasteritorial. Dunia global sebagai sebuah peradaban baru yang merupakan rentetan kemajuan berfikir manusia dari satu generasi ke generasi berikutnya. ${ }^{1}$ Hari ini manusia sedang memasuki sebuah babak dari perputaran zaman yaitu era revolusi industri $4.0^{2}$ bahkan menuju society5.0. ${ }^{3}$ Sebuah zaman yang tidak pernah terbayangkan sebelumnya. Suatu era yang ditandai dengan kemajuan teknologi komputer yang dahsyat, sebuah revolusi yang mengintegrasikan efek parallel dari teknologi eksponen yang multi menjadi sebuah kekuatan baru dalam kehidupan. Kedahsyatan era ini mampu menjadikan segala sesuatu menjadi Simple (sederhana), Faster (cepat), Cheaper (murah), dan Accessible (mudah diakses) ${ }^{4}$.

Pengaruh dunia global ini memaksa manusia menjadi generasi milenium yang serba electrical. Kehidupan manusia tidak dapat luput dari persentuhan mesincanggih yang serba digital. Efek dari digitalisasi peradaban manusia ini tidak hanya menyentuh secara langsung terhadap masalah kehidupan yang bersifat profan namun menyeret ke hal-hal yang bersifat sakral. Sebagai salah satu contoh akad atau transaksi muamalah yang dilakukan oleh umat Islam harus bermetamorfosis dengan sistem baru ini tanpa meninggalkan nila-nilai syari'at.

Syariat Islam sebagai ajaran yang selalu adaptif atau shalih li kulli zaman wa makan dipacu untuk beradaptasi dengan dunia digital ini. Salah satu syariat yang sudah menjadi tradisi umat Islam di dunia adalah wakaf. ${ }^{5}$ Selama ini pendayagunaan wakaf masih dilakukan secara tradisional sehingga penerima manfaat dari wakaf tersebut tidak bisa dirasakan oleh masyarakat secara luas ${ }^{6}$. Indonesia merupakan salah satu negara yang memiliki asert wakaf yang banyak. Berdasarkan data Sistem Informasi Wakaf (SIWAK) Kementerian Agama RI jumlah tanah wakaf mencapai 51.548,68 Ha yang tersebar 382.889 lokasi ${ }^{7}$.

Dari sejumlah aset wakaf yang tersebar di seluruh penjuru nusantara ini, pondok pesantren merupakan salah satu lembaga yang dianggap 
mampu mendayagunakan wakaf secara produktif.Walaupun jumlah aset wakaf pesantren tidak sebanyak penggunaan lainnya yaitu masjid, mushalla dan lainnya, akan tetapi produktifitas aset wakaf oleh pesantren lebih baik. Pesantren menggunakan aset wakaf sebagai sekolah, madrasah, asrama bahkan tidak sedikit yang diproduktifkan memalui usaha ekonomi pesantren.

Dari beberapa contoh institusi pesantren sebagai nazhir wakaf yang mampu mendayagunakan wakafnya adalah Pondok Pesantren Gontor, Tebuireng ${ }^{8}$, dan masih banyak pesantren lainnya. Ini sebagai indikator bahwa pesantren mampu mendayagunakan aset wakaf secara produktif. Beberapa pondok pesantren mengembangkan cabangnya di beberapa daerah untuk mendayagunakan aset wakaf yang diwakafkan kepada pesantren tersebut.

Di era digital sekarang, pesantren memiliki peluang atau prospek untuk meningkatkan fungsi nazhir lebih luas lagi. Tidak hanya mengelola aset wakaf yang berada di wilayah Indonesia tetapi juga menjadi nazhir global yang mengelola secara profesional aset wakaf internasional tanpa sekat teritorial. Pesantren di era sekarang, sudah seharusnya adaptif dan menangkap peluang besar sejalan dengan perkembangan kontemporer saat ini. Ciri-ciri pesantren masa depan ada 3 (tiga), yaitu: ledakan ilmu pengetahuan dan teknologi, kompetitif, moral dan pluralisme. ${ }^{9}$

Rintisan wakaf secara global sudah dimulai dengan penyelenggaran tahunanGlobal Waqf Conference. Termasuk 7th Global Waqf Conference 2019 (GWC2019) yang diselenggarakan pada tanggal 10 - 13 Nopember 2019 di Malaysia telahmenggagas bebarapa hal diantaranya solusi alternatif untuk pengembangan wakaf melalui penggunaan teknologi baru, mengeksplorasi standardisasi peraturan wakaf secara global, prospek aplikasi wakaf untuk memenuhi kebutuhan milenium. Bahkan World Congress of Muslim Philanthropists (WCMP) yang bermarkas di Amerika pun pernah menyelenggarakan Global Donor Forum 2012 yang diselenggarakan di Malaysia juga pada 26-28 April $2012{ }^{10}$. 
Jauh sebelum perhelatan tingkat dunia tersebut, para pakar ekonomi Islam menyerukan rintisan wakaf secara global. Termasuk dalam Forum The Second Harvard Forum on Islamic Finance pada tahun 1998, MA. Mannan menyarankan agar pada abad ke-21 ini bank-bank Islam berusaha memobilisasi secara global dan mewujudkan target Wakaf Tunai sebesar US\$1 milyar pada tahun 2010, terutama melalui penjualan Sertifikat Wakaf Tunai untuk mendukung pembangunan SDM dan infrastruktur sosial dunia Islam khususnya, dan menolong orang-orang kurang beruntung di seluruh dunia tanpa terkecuali. ${ }^{11}$

Tulisan ini akan mengkaji bagaimana peluang pondok pesantren sebagai nazhir wakaf global. Dengan menggunakan metode kualitatif yang bersumber dari kajian literatur atau literature review, kemudian dianalisis bagaimana faktor pendukung yang berupa kekuatan dan peluang serta faktor penghambat berupa kelemahan. Dengan anlisis ini dapat dilihat bagaimana prospek pesantren untuk menjadi nazhir wakaf global di era digital sekarang ini.

\section{B. Hasil dan Pembahasan}

\section{Potensi Wakaf di Indonesia}

Tidak salah jika Indonesia disebut sebagai negara yang memiliki potensi wakaf terbesar di dunia. Jika dilihat potensi tanah wakaf di seluruh Indonesia, lahan wakaf yang tersebar di seluruh Indonesia menurut data dari Kementerian Agama RI tersebar di 381.860 lokasi dengan luas 51.251,21 Ha. Dari jumlah seluas tersebut ternyata baru sebanyak 61,12 \% lahan wakaf yang sudah bersertifikat. ${ }^{12}$ Data-data tersebut dapat dilihat pada tabel 1 di bawah ini. 
Tabel 1

Jumlah Tanah Wakaf Seluruh Indonesia

\begin{tabular}{|c|c|c|c|c|c|c|c|}
\hline \multirow{2}{*}{ No } & \multirow{2}{*}{ Nama Wilayah } & \multirow{2}{*}{ Jumlah } & \multirow{2}{*}{ Luas $[\mathrm{Ha}]$} & \multicolumn{2}{|c|}{ Sudah Sertifikat } & \multicolumn{2}{|c|}{ Belum Sertifikat } \\
\hline & & & & Jumlah & Luas $[\mathrm{Ha}]$ & Jumlah & Luas [Ha] \\
\hline 1. & Aceh & 14.032 & $7.675,48$ & 6.822 & 961,19 & 7.210 & $6.714,29$ \\
\hline 2. & Sumatera Utara & 10.857 & $8.223,16$ & 6.257 & 793,51 & 4.600 & $7.429,65$ \\
\hline 3. & Sumatera Barat & 5.235 & 596,58 & 3.604 & 373,13 & 1.631 & 223,44 \\
\hline 4. & Riau & 8.123 & $2.096,61$ & 2.816 & 457,64 & 5.307 & $1.638,98$ \\
\hline 5. & Jambi & 6.360 & $1.003,69$ & 3.515 & 444,48 & 2.845 & 559,21 \\
\hline 6. & Sumatera Selatan & 3.966 & 944,81 & 1.961 & 146,96 & 2.005 & 797,86 \\
\hline 7. & Bengkulu & 2.294 & 408,69 & 1.643 & 235,17 & 651 & 173,52 \\
\hline 8. & Lampung & 12.790 & $5.642,35$ & 7.340 & $2.824,45$ & 5.450 & $2.817,90$ \\
\hline 9. & Kep. Bangka Belitung & 1.089 & 203,47 & 749 & 150,42 & 340 & 53,06 \\
\hline 10. & Kepulauan Riau & 1.456 & 282,31 & 458 & 63,80 & 998 & 218,51 \\
\hline 11. & D K I Jakarta & 6.593 & 266,18 & 4.074 & 157,45 & 2.519 & 108,73 \\
\hline 12. & Jawa Barat & 72.169 & $5.080,04$ & 39.055 & $2.219,84$ & 33.114 & $2.860,20$ \\
\hline 13. & Jawa Tengah & 99.450 & $5.076,09$ & 72.778 & $3.633,02$ & 26.672 & $1.443,07$ \\
\hline 14. & D I Yogyakarta & 10.078 & 358,48 & 9.121 & 320,86 & 957 & 37,62 \\
\hline 15. & Jawa Timur & 66.402 & $4.367,55$ & 35.211 & $2.255,68$ & 31.191 & $2.111,87$ \\
\hline 16. & Banten & 15.416 & $1.072,21$ & 8.581 & 552,08 & 6.835 & 520,13 \\
\hline 17. & Bali & 1.452 & 212,39 & 1.301 & 186,25 & 151 & 26,15 \\
\hline 18. & Nusa Tenggara Barat & 8.979 & $1.360,64$ & 5.767 & 867,91 & 3.212 & 492,73 \\
\hline 19. & Nusa Tenggara Timur & 1.307 & 335,26 & 985 & 209,90 & 322 & 125,36 \\
\hline 20. & Kalimantan Barat & 2.697 & 532,74 & 1.542 & 245,54 & 1.155 & 287,20 \\
\hline 21. & Kalimantan Tengah & 3.029 & 610,63 & 1.829 & 338,78 & 1.200 & 271,85 \\
\hline 22. & Kalimantan Selatan & 7.970 & 928,58 & 7.104 & 801,30 & 866 & 127,28 \\
\hline 23. & Kalimantan Timur & 2.563 & 656,07 & 1.252 & 197,68 & 1.311 & 458,39 \\
\hline 24. & Kalimantan Utara & 418 & 134,54 & 158 & 98,76 & 260 & 35,78 \\
\hline 25. & Sulawesi Utara & 775 & 102,78 & 344 & 34,40 & 431 & 68,37 \\
\hline 26. & Sulawesi Tengah & 2.145 & 895,07 & 1.369 & 138,60 & 776 & 756,47 \\
\hline 27. & Sulawesi Selatan & 7.109 & 905,78 & 4.432 & 361,20 & 2.677 & 544,58 \\
\hline
\end{tabular}




\begin{tabular}{|l|l|c|c|c|c|c|c|}
\hline \multirow{2}{*}{ No } & \multirow{2}{*}{ Nama Wilayah } & \multirow{2}{*}{ Jumlah } & \multirow{2}{*}{ Luas [Ha] } & \multicolumn{2}{|c|}{ Sudah Sertifikat } & \multicolumn{2}{c|}{ Belum Sertifikat } \\
\cline { 5 - 9 } & & & & Jumlah & Luas [Ha] & Jumlah & Luas [Ha] \\
\hline 28. & Sulawesi Tenggara & 1.108 & 110,58 & 827 & 71,37 & 281 & 39,21 \\
\hline 29. & Gorontalo & 1.852 & 383,30 & 937 & 271,42 & 915 & 111,88 \\
\hline 30. & Sulawesi Barat & 3.027 & 536,92 & 960 & 115,30 & 2.067 & 421,62 \\
\hline 31. & Maluku & 469 & 121,36 & 213 & 38,96 & 256 & 82,39 \\
\hline 32. & Maluku Utara & 313 & 46,72 & 225 & 25,37 & 88 & 21,35 \\
\hline 33. & Papua & 287 & 59,97 & 141 & 19,28 & 146 & 40,69 \\
\hline 34. & Papua Barat & 50 & 20,17 & 35 & 6,19 & 15 & 13,98 \\
\hline \multicolumn{2}{|c}{ Jumlah } & 381.860 & $51.251,21$ & 233.406 & $19.617,89$ & 148.454 & $31.633,31$ \\
\hline
\end{tabular}

Dari sebaran tanah wakaf yang begitu luas, belum semua produktif. Pengertian produktif di sini adalah transfrmasi dari pengelolaan wakaf yang alami menjadi pengelolaan wakaf yang profesional untuk meningkatkan atau menambah manfaat wakaf. ${ }^{13}$ Menuruthasil penelitian, ternyata harta wakaf lebih banyak bersifat diam (77\%) daripada yang menghasilkan atau produktif (23\%). Termasuk wakaf lebih banyak dikelola oleh perseorangan (66\%) alias tradisional, daripada organisasi professional (16\%) dan berbadan hukum (18\%). ${ }^{14}$

Dibandingkan dengan negara-negara lain, perwakafan di Indonesia masih tertinggal jauh. Sebagai contoh negara Mesir, Aljazair, Sudan, Kuwait, dan Turki yang sudah jauh-jauh hari mengelola wakaf ke arah produktif. Bahkan negara tetangga kita yaitu Singapura memiliki aset jika dikruskan berjumlah S\$ 250 juta. Pengelolaan wakaf di negara kecil ini dilakukan oleh Majelis Ugama Islam Singapura (MUIS) dengan membuat anak perusahaan bernama Wakaf Real Estate Singapura. ${ }^{15}$

Seperti yang disampaikan oleh Uswatun Hasanah ada beberapa faktor penyebab wakaf di Indonesia belum dapat berperan secara produktif dalam pemberdayaan ekonomi umat Islam di Indonesia, diantaranya karena: Pertama, masalah pemahaman masyarakat tentang hukum wakaf yang masih belum memahami hukum wakaf dengan baik dan benar, baik dari segi rukun dan syarat wakaf, maupun maksud disyari'atkan wakaf. 
Kedua, pengelolaan dan manajemen wakaf yang tidak professional. Ketiga, obyek wakaf yang cenderung berupa aset statis yang sulit dikembangkan. Keempat, nazir yang kurang profesional. ${ }^{16}$

Jelas, faktor nazhir sangat berperan dalam pengembangan wakaf produktif. ${ }^{17}$ Nazhir wakaf di Indonesia kebanyakan masih terbilang tradisional dan cenderung bersifat konsumtif (non-produktif). Pemanfaatan asetwakafkebanyakanbarudigunakanuntukpembangunan masjid dan kuburan. ${ }^{18}$ Padahal kalau berkaca pada negara lain, seperti Iran, wakaf sudah merambah pada pembiayaan sektor infra struktur, wisata, dan layanan kesehatan sejak abad ke-10 masehi, termasuk wakaf al-Azhar di Mesir, bahkan Kuwait Awqaf Publik Foundation (KAPF) telah mampu mengantarkan wakaf di Kuwait menjadi institusi yang mandiri dan mampu menopang kehidupan sosial ekonomi negara. ${ }^{19}$

\section{Wakaf di Era Digital}

Era digital sekarang menjadikan manusia berhijrah dari interaksi offline ke online. Sebagai contoh orang kini lebih memilih berjual beli melaui market place. Beraneka jenis kemudahan ini memberikan ruang siapapun untuk bertransaksi, berbisnis, bahkan aktifitas yang tanpa aturan sekalipun

Dengan adanya era digital ini, manusia sudah sangat terbiasa dengan Electronic Commerce (e-Commerce) atau suatu transaksi yang dapat dilakukan secara elektronik, yang meliputi perdagangan via Internet (Internet Commerce), fasilitas Web Internet (Web Commerce), dan Sistem Pertukaran Data Terstuktur Secara Elektronik (Electronic Data Interchange).

Era digital menjadikan segala transaksi semakin mudah, termasuk berwakaf. Salah satu media untuk memperkenalkan dan menggali potensi wakaf terutama kaum milineal adalah dengan digitalisasi. Seperti yang dilansir oleh Badan Wakaf Indonesia, untuk memanfaatkan peluang ini, BWI sudah memulai gerakan digitalisasi wakaf dengan mendorong para nazhir atau pengelola wakaf untuk memanfaatkan teknologi digital. ${ }^{20}$ 
Kesempatan menglobalkan wakaf ke seluruh penjuru dunia tidak sulit, karena piranti untuk menjembatani hal tersebut sudah sangat mudah didapatkan. Teknologi digital membawa manusia menuju serba mudah dan murah. Berwakaf di era digital sangat mudah, terlebih regulasi memberikan peluang sangat luas. Seperti halnya dalam pasal 16 Undang-Undang Nomor 41 tahun 2004 tentang wakaf disebutkan bahwa salah satu harta wakaf benda bergerak adalah uang. Wakaf uang adalah wakaf berupa uang yang dapat dikelola secara produktif, hasilnya dimanfaatkan untuk mauquf alaih. ${ }^{21}$

Selain wakaf uang, ada benda bergerak yang dapat dijadikan objek wakaf yaitu wakaf hak cipta, wakaf hak merk, wakaf hak paten, wakaf hak desain industri, wakaf rahasia dagang, wakaf hak desain tata letak sirkuit terpadu, dan wakaf hak perlindungan varietas tanaman. ${ }^{22}$ Lebih jauh di era digital ini muncul ijtihad baru terkait wakaf saham syariah ${ }^{23}$ dengan dua model pengelolaan wakaf saham, yaitu wakaf korporasi dan wakaf saham perorangan, ${ }^{24}$ dan juga wakaf wasiat polis asuransi syariah. $^{25}$

Untuk memantapkan digitalisasi wakaf, sekarang sudah mulai dirancang aplikasi teknologi untuk pengelolaan wakaf yang bernama Blockhain.Sebagaimana disampaikan oleh Raditya Sukmana, bahwa pengelolaan wakaf produktif dengan Blockchain memungkinkan peningkatan efisiensi dan efektivitas dari tiga sisi. ${ }^{26}$

Pertama, jika wakif dan nazhir terhubung pada suatu sistem Blockchain, maka transaksi donasi wakaf dapat dilakukan dengan simultan secara digital dan transparans. Kedua, apabila wakaf berbasis Blockchain dapat menjangkau nazhir wakaf global, sangat mungkin wakif dari suatu negara berwakaf di negara lain, terutama negara yang membutuhkan pendanaan pembangunan. Hal itu dapat mewujudkan dampak pengelolaan wakaf produktif yang bersifat inklusif pada skala global.

Ketiga, sistem Blockchain sebagai suatu rekaman bersama atas transaksi dalam suatu komunitas digital yang menghubungkan wakif selaku 
donatur wakaf, nazhir (pengelola wakaf), hingga mauquf 'alaih atau penerima wakaf memungkinkan seluruh pihak untuk saling mengawasi, terutama terkait dengan pengelolaan wakaf oleh nazir. Dengan hal tersebut, transparansi pengelolaan wakaf dapat terjaga dengan baik dan dapat mencegah potensi penyalahgunaan dalam pengelolaan wakaf

\section{Pesantren Sebagai Nazhir Wakaf}

Pesantren yang tersebar di seluruh penjuru Indonesia dengan jumlah ribuan pondok pesantren, memiliki sebutan nama yang berbeda, sesuai dengan kekhasan daerah masing-masing. Nama pesantren diebut dengan dayah dan rangkang di Aceh, atau surau di Sumatra Barat, dan pondok pesantren di Jawa ${ }^{27}$. Jumlah Pondok Pesantren di Indonesia sampai tahun 2015 sebanyak 28.961 buah ${ }^{28}$ dengan sebaran tiap provinsi sebagaimana dapat dilihat pada tabel 2.

\section{Tabel 2}

Jumlah Pondok Pesantren Berdasarkan Tipe Pondok Pesantren

Tahun Pelajaran 2014/2015

\begin{tabular}{|c|l|l|}
\hline No. & \multicolumn{1}{|c|}{ Provinsi } & $\begin{array}{c}\text { Jumlah Pondok } \\
\text { Pesantren }\end{array}$ \\
\hline 1 & Aceh & 1.222 \\
\hline 2 & Sumatera Utara & 175 \\
\hline 3 & Sumatera Barat & 216 \\
\hline 4 & Riau & 190 \\
\hline 5 & Jambi & 186 \\
\hline 6 & Sumatera Selatan & 356 \\
\hline 7 & Bengkulu & 68 \\
\hline 8 & Lampung & 694 \\
\hline 9 & Kep. Bangka Belitung & 45 \\
\hline 10 & Kep. Riau & 48 \\
\hline 11 & DKI Jakarta & 124 \\
\hline 12 & Jawa Barat & 9.167 \\
\hline
\end{tabular}




\begin{tabular}{|l|l|l|}
\hline 13 & Jawa Tengah & 4.685 \\
\hline 14 & DI Yogyakarta & 247 \\
\hline 15 & Jawa Timur & 6.044 \\
\hline 16 & Banten & 3.435 \\
\hline 17 & Bali & 88 \\
\hline 18 & Nusa Tenggara Barat & 550 \\
\hline 19 & Nusa Tenggara Timur & 27 \\
\hline 20 & Kalimantan Barat & 235 \\
\hline 21 & Kalimantan Tengah & 79 \\
\hline 22 & Kalimantan Selatan & 215 \\
\hline 23 & Kalimantan Timur & 141 \\
\hline 24 & Kalimantan Utara & 14 \\
\hline 25 & Sulawesi Utara & 16 \\
\hline 26 & Sulawesi Tengah & 103 \\
\hline 27 & Sulawesi Selatan & 294 \\
\hline 28 & Sulawesi Tenggara & 90 \\
\hline 29 & Gorontalo & 25 \\
\hline 30 & Sulawesi Barat & 98 \\
\hline 31 & Maluku & 14 \\
\hline 32 & Maluku Utara & 14 \\
\hline 33 & Papua & 33 \\
\hline 34 & Papua Barat & 23 \\
\hline & Jumlah & 28.961 \\
\hline & & \\
\hline
\end{tabular}

Sebaran pesantren di Indonesia yang begitu hebat merupakan raksasa potensial yang akan menopang kemajuan ekonomi negara Indonesia. Untuk hal tersebut Kementerian Agama RI mempromosikan "Trilogi Pengembangan Pesantren" yang mencakup: (1) Pesantren sebagai lembaga keagamaan yang mengajarkan ilmu-ilmu agama dan nilai-nilai Islam (tajaqquh fi ad-din). (2) Pesantren sebagai lembaga pendidikan yang menjadi wadah pengembangan ilmu pengetahuan dan teknologi (sains), ekonomi, dan budaya. (3) Pesantren sebagai lembaga sosial yang menjaga harmoni masyarakat, melakukan kontrol sosial, dan rekayasa sosial. 
Termasuk wakaf ${ }^{29}$ di pesantren ibarat seperti dua sisi mata uang yang tak dapat dipisahkan satu sama lainnya. Eksistensi pesantren sejak berdiri sampai menjadi lembaga pendidikan yang tersebar di seluruh Indonesia, tidak terlepas dari wakaf. Kemandirian pesantren yang merupakan lembaga asli (indigenous) Indonesia ${ }^{30}$ secara jelas ditopang oleh wakaf.

Tidak semua wakaf pesantren dikelola dengan manajemen yang baik, tapi eksistensi pesantren masih dipercaya oleh oleh masyarakat sebagai pemegang amanah wakaf (nazhir), baik berupa masjid, madrasah, sekolah dan lain sebagainya. ${ }^{31}$ Dari modal wakaf ini pesantren mampu mengembangkan wakaf yang luar biasa menjadi produktif, walaupun jumlah tanah wakaf untuk pesantren secara statistik baru 3,48\% dari seluruh penggunaan tanah wakaf di Indonesia. Dalam tabel 3 di bawah ini kita dapat mencermati penggunaan tanah wakaf di Indonesia.

Tabel 3

Penggunaan Tanah Wakaf ${ }^{32}$

\begin{tabular}{|c|l|l|}
\hline No & \multicolumn{1}{|c|}{ Penggunaan } & \multicolumn{1}{c|}{ Prosentase } \\
\hline 1 & Mushalla & $28,41 \%$ \\
\hline 2 & Masjid & $44,36 \%$ \\
\hline 3 & Makam & $4,45 \%$ \\
\hline 4 & Sekolah & $10,68 \%$ \\
\hline 5 & Pesantren & $3,48 \%$ \\
\hline 6 & Sosial lainnya & $8,61 \%$ \\
\hline
\end{tabular}

Dari 3,48\% ini, tidak sedikit pondok pesantren yang mampu mengembangkan wakafnya sangat produktif. Sebut saja PesantrenGontor yang memulai penggalangan dana sejak tahun 1931 melalui divisi khizanahnya. Dari hasil tersebut, sebagian menjadi harta wakaf yang diserahkan dalam ikrar wakaf. ${ }^{33}$ Pada tahun 1958 pondok pesantren Gontor memiliki aset tanah sebanyak 18,59 hektar, maka pada tahun 2009 aset tanah pesantren ini berkembang menjadi 825,184 hektar, dan kurang lebih 651 hektar diantaranya merupakan tanah wakaf. Aset tanah 
tersebut diperoleh melalui wakaf, hibah, tukar menukar, dan pembelian. Di samping itu, pesantren ini telah menginvestasikan aset wakafnya dalam 27 unit usaha produktif. ${ }^{34}$

Selain pesantren Gontor, Pondok Pesantren Darunnajah Jakarta memliki asset wakaf mencapai 5.063.791 m²,35esantren Asshiddiqiyah mencapai aset tanah seluas sekitar 15 hektar, ${ }^{36}$ Pesantren Tebuireng Jombang memiliki aset seluas $405.824 \mathrm{~m}^{2,37}$ Pesantren Daarut Tauhiid memiliki tanah seluas $9.882 \mathrm{~m} 2$ yang terletak daerah Geger Kalong Bandung dan 1,5 ha di luar Bandung, selain produktifitas pengembangan ekonomi umat yang maju. ${ }^{38}$ Beberapa nama Pesantren tersebut dapat dijadikan rujukan dan contoh dalam pengembangan ekonomi keumatan berbasis wakaf.

Paradigma wakaf produktif ini menjadi tuntutan bagi institusi pesantren. Hal ini disebabkan karena pesantren merupakan bagian dari institusi wakaf mayoritas di Indonesia. Pesantren telah teruji selama berabad-abad tampil sebagai contoh dalam pengelolaan wakaf yang baik dan profesional meskipun dalam takaran kemampuan masing-masing pesantren.

\section{Dari Nazhir Lokal Menuju Global}

Dalam pasal 6 Undang-undang No 41 Tahun 2004 tentang wakaf disebutkan bahwa wakaf dapat dilaksanakan dengan memenuhi unsurunsur sebagai berikut: a. Wakif; b. Nazhir; c. Harta Benda Wakaf; d. Ikrar Wakaf; e. peruntukan harta benda wakaf; f. jangka waktu wakaf. ${ }^{39}$ Dari unsur-unsur yang termaktub dalam perundang-undangan tersebut, terdapat salah satu unsur yang dianggap memiliki peran penting dan strategis yaitu nazhir. ${ }^{40}$

Kata nazhir secara bahasa berasal dari akar kata nazara yang berarti ra'a (melihat) abshara (memandang) dan tadabbara (merenungkan, memikirkan, mempertimbangkan) ${ }^{41}$ Secara istilah pengertian nazhir dapat merujuk kepada pasal 1 ayat 4 Undang-undang No 41 Tahun 
2004 tentang wakaf yang menyebutkan bahwa nazhir adalah pihak yang menerima harta benda wakaf dari Wakif untuk dikelola dan dikembangkan sesuai dengan peruntukannya. ${ }^{42}$

Untuk mendayagunakan wakaf, nazhir memiliki tugas yaitu: a. melakukan pengadministrasian harta benda wakaf; $b$. mengelola dan mengembangkan harta benda wakaf sesuai dengan tujuan, fungsi, dan peruntukannya; c. mengawasi dan melindungi harta benda wakaf; $d$. melaporkan pelaksanaan tugas kepada Badan Wakaf Indonesia. ${ }^{43}$

Dalam Undang-undang No 41 Tahun 2004 disebutkan juga bahwa nazhir tidak hanya perorangan saja tapi terdiri dari nazhir perorangan, organisasi atau badan hukum. ${ }^{44}$ Syarat-syarat untuk nazhir perseorangan adalah warga negara Indonesia, Islam, dewasa, amanah, mampu secara jasmani dan rohani serta tidak terhalang melakukan perbuatan hukum. Untuk nazhir organisasi harus memenuhi persyaratan: (1) pengurus organisasi yang bersangkutan memenuhi syarat-syarat nazhir perorangan. (2) organisasi tersebut bergerak di bidang sosial, pendidikan, kemasyarakatan dan atau keagamaan Islam. Sedangkan nazhir badan hukum memiliki syarat sebagai berikut: (1) pengurus Badan Hukum yang bersangkutan memenuhi syarat-syarat nazhir perorangan. (2) Badan Hukum Indonesia yang dibentuk sesuai dengan peraturan perundang-undangan yang berlaku. (3) Badan Hukum yang bersangkutan bergerak di bidang sosial, pendidikan, kemasyarakatan dan atau keagamaan Islam. ${ }^{45}$

Dari persayaratan tersebut pondok pesantren dapat mengambil peran sebagai nazhir badan hukum, karena semua pondok pesantren harus memiliki Ijin Operasional dengan persayaratan memiliki akta Notaris. ${ }^{46}$ Kesempatan ini menjadi peluang untuk menjadikan pondok pesantren sebagai nazhir wakaf global. Maksud dari nazhir wakaf global di sini adalah nazhir internasional dalam arti menerima serta mengelola wakafwakaf internasional dengan mengacu kepada kesepakatan dari Global Waqf Conference dan Forum The Second Harvard Forum on Islamic Finance. 
Nazhir wakaf global tidak dibatasi teritorial atau lokal dalam ruang lingkup Negara Kesatuan Republik Indonesia saja. Demikian juga kemanfaatannya tidak hanya secara lokal tetapi mencakup seluruh dunia, sehingga dari hasil wakaf ini dapat dimanfaatkan untuk kepentingan kemanfaatan kemanusiaan di seluruh dunia.

Jika dicermati, pesantren memiliki kekuatan (strenght) untuk mengembangkan wakaf lebih luas lagi. Dalam hal ini pesantrensangat siap dan prospektif melangkah untuk menjadi nazhir global atau internasional, karena pesantren sangat potensial dengan beberapa keistimewaannya.

Terdapat beberapa faktor pendukung pesantren prospektif menjadi nazhir wakaf global. Hal ini dikarenakan pesantren memiliki potensi dan faktor pendukung lainnya, diantaranya:

\section{a. Era Digital}

Era digital saat ini dapat dikatakan sebagai pintu masuk menuju dunia wakaf global. Karena hanya dengan menggunakan kecanggihan teknologi informasi, pengelolaan wakaf oleh pesantren secara global mampu diwujudkan.

b. Jumlah Pesantren di Indonesia

Tersebarnya jumlah pesantren di seluruh provini se-Indonesia dapat dijadikan sebagai pendukung globalisasi wakaf. Pesantren-pesantren yang tersebar dapat didayagunakan sebagai nazhir profesional dan dipersiapkan untuk menjadi nazhir global.

\section{c. Pengalaman Pesantren}

Pesantren sebagai lembaga pengelola aset wakaf yang sudah berpengalaman selama berabad-abad. Sejak kehadiran pesantren di nusantara sampai saat ini pesantren tidak terlepas dari dunia wakaf. Kemandirian pesantren pun diawali dari keberadaan aset wakaf yang dikelola dengan baik oleh pesantren. 


\section{d. Sebagai Lembaga Pendidikan Agama Terpercaya}

Sebagai lembaga pendidikan Islam, pesantren sangat potensial menjadi pusat pengembangan filantropi wakaf di Indonesia bahkan dunia.Hal ini dapat dilihat dari track record pesantren sebagai institusi yang berkutat dengan kajian ilmu-ilmu keislaman, termasuk diantaranya figh. Dari segi basis keilmuan dan wawasan tentang teori perwakafan pesantren sudah tidak diragukan lagi kemampuannya. Selain itu pesantren sangat dipercaya oleh masyarakat sebagai lembaga institusi keagamaan yang amanah. Seperti yang disampaikan oleh Azyumardi Azra bahwa kepercayaan masyarakat kepada pesantren masih tinggi karena masyarakat masih berharap besar kepada pesantren untuk berperan penting dalam segala hal(expected role). ${ }^{47}$

Termasuk dalam masalah penyerahan aset wakaf. Sudah sejak lama masyarakat menyerahkan harta kekayaan untuk diwakafkan kepada pesantren. Pesantren sangat dipercaya sebagai nazhir yang akan mengelola secara produktif aset wakaf yang diserahkan oleh masyarakat. Salah satu contoh kepercayaan masyarakat terhadap nazhir pesantren adalah apa yang diwakafkan masyarakat kepada pondok pesantren Tebuireng Jombang. Dari total 405.824 M2 aset tanah wakaf Yayasan Hasyim Asy'ari Pesantren Tebuireng Jombang, wakaf dari K.H. Hasyim Asy'ari seluas 137.850 M2, pembelian yang diatasnamakan wakaf Tebuireng seluas 118.436 M2 dan wakaf dari masyarakat kepada pesantren seluas $149.532 \mathrm{M} 2$, dan. $^{48}$

\section{e. Dukungan Regulasi}

Salah satu pendorong berkembangnya perwakafan di Indonesia adalah adanya dukungan regulasi. Dengan regulasi baru, pesantren saat ini bukan lagi merupakan institusi pendidikan kelas dua, tapi pesantren hadir sebagai salah satu wadah pendidikan yang setara dengan lembaga pendidikan lainnya. Dengan terbitnya Undang-undang Nomor 4 tahun 2019 tentang Pesantren, ${ }^{49}$ eksistensi lembaga pendidikan asli Indonesia ini telah dikembalikan ke posisi sebelumnya yakni sebagai lembaga 
pendidikan yang diakui secara legal formal oleh negara.

Selain payung hukum berupa Undang-undang tentang Pesantren, dalam menyongsong kesiapan menjadi nazhir wakaf global pesantren memiliki payung hukum tentang perwakafan. Seperti masuknya materi perwakafan dalam Kompilasi Hukum Islam yang dimuat dalam Inpres Nomor 1 tahun 1991, hadirnya Undang-undang nomor 41 tahun 2004 tentang wakaf, bahkan dalam pasal 49 UU No. 3 tahun 2006 tentang Pengadilan Agama disebutkan: “Peradilan Agama bertugas dan berwenang memeriksa, memutus, dan menyelesaikan perkara di tingkat pertama antara orang-orang yang beragama Islam di bidang: a. Perkawinan; b. Waris; c. Wasiat; d. Hibah; e. Wakaf; f. Zakat; g. Infaq; h. Shadaqah; dan i. Ekonomi syariah..$^{50}$

Dengan adanya payung regulasi ini, pesantren akan semakin leluasa mengembangkan wakaf, termasuk secara prospektif memiliki kesiapan untuk mengelola wakaf internasional. Karena aspek hukum adalah segalanya dalam memasuki medan yang lebih luas lagi. Bahkan lebih dari itu pemerintah pun mendirikan Badan Wakaf Indonesia, ${ }^{51}$ sebuah lembaga independen yang bertujuan membina para nazhir agar mengelola aset lebih produktif dan bermanfaat. BWI dapat dijadikan sebagai mitra konsultasi dengan pesantren dalam mengelola wakaf oleh pesantren supaya memiliki kemanfaatan lebih luas lagi.

Selain kekuatan dan kesempatan yang telah dipaparkan di atas, pesantren juga perlu mawas diri dengan melihat kelemahan yang akan mereduksi program mulia sebagai pengelola wakaf global. Pesantren memiliki beberapa kelemahan diantaranya karena tidak adanya kesiapan perangkat.

Tidak semua pesantren memiliki kesiapan bertransformasi dengan dunia digital. Hal ini dikarenakan beberapa faktor: Pertama, tingkat kesibukan tingkat tinggi dalam melaksanakan rutinitas kegiatan belajar mengajar di beberapa pondok. Sehingga tingkat kedisplinan merupakan faktor utama bagi dewan kyai, asatidz dan para santri. Kedua, masih 
ada beberapa pesantren yang melarang penggunaan media teknologi informasi ini karena dikhawatirkan akan lalai dari pelajaran yang yang dikaji selama di pesantren. ${ }^{52}$

Sesungguhnya aspek ini bukan merupakan hal yang urgen. Pesantren masih dapat berbenah dengan lebih mengenal lagi teknologi. Ibarat sebilah pisau yang memiliki dua sisi kebaikan dan keburukan bagi pengguannya. Kebaikan untuk kemanfaatan dan keburukan apabila digunakan untuk kejahatan.

\section{Kesimpulan}

Digitalisasi merupakan pintu masuk ke dunia global. Saat ini manusia dipaksa untuk masuk dunia baru yang tidak mengenal batas teritorial. Semua aktifitas dapat dilakukan dengan sangat sederhana, mudah, murah dan cepat. Termasuk wakaf yang merupakan syariat Islam yang sudah menjadi tradisi dunia. Wakaf akan semakin produktif apabila nazhir sebagai pemegang kendali pengelolaannya lebih profesional.

Pesantren termasuk salah satu lembaga yang sudah sangat berpengalaman dalam pengelolaan wakaf. Beberapa pesantren di Indonesia telah memperlihatkan prestasinya dalam mengelola dan mengembangkan wakaf sehingga kemanfaatannya lebih luas dirasakan umat.

Memasuki era digital pesantren dituntut untuk mengembangkan fungsi kenazhirannya tidak hanya bersifat lokal tapi menjajaki dunia global atau internasional. Rintisan-rintisan wakaf global sudah mulai didengungkan dengan diselenggarakannya beberapa konferensi dunia tentang wakaf global.

Berangkat dari pengalaman yang sangat panjang dalam mengelola wakaf, tersebarnya jumlah pesantren seluruh Indonesia, pesantren sangat prospektif untuk menjadi nazhir wakaf global. Selain faktor pendukung lainnya yaitu karena pesantren masih dianggap sebagai lembaga pendidikan yang terpercaya. Dalam arti masyarakat masih menaruh 
kepercayaan tinggi terhadap pesantren untuk mengelola wakaf.

Faktor pendukung lainnya adalah karena adanya dukungan regulasi. Selain Undang-Undang pesantren yang mengokohkan jati diri pesantren di depan hukum formal, juga terdapat perundang-undangan yang memayungi hukum perwakafan di Indonesia. Walaupun ada beberapa faktor penghambat yang muncul akibat kelemahan dan kekurangan pesantren yaitu karena masih ada pesantren yang tidak memiliki kesiapan dalam hal perangkat teknologi informasi. Akan tetapi bukan berarti pesantren tidak prospektif menjadi nazhir wakaf global. Karena hal itu hanya terjadi di beberapa pesantren dan tidak dapat dijadikan generalisasi untuk seluruh pesantren di Indonesia. Disamping itu, kelemahan tersebut tidak sangat urgen dan berpengaruh besar karena hal itu masih dapat diperbaki dengan literasi yang baik. 


\section{Daftar Pustaka}

Abbasi, Muhammad Zubair, 'The Classical Islamic Law of Waqf: A Concice Introduction', Arab Law Quarterly, 26.2 (2012), 121-53

Athoillah, H. M., Hukum Wakaf Benda Bergerak, 1st edn (Sumedang: Alqaprint Jatinangor, 2012)

A. Faishal Haq, Wakaf Kontemporer, dari Teori ke Aplikasi, sumber http:// muslim-shared.blogspot.com/2016/01/wakaf-kontemporer-dariteori-ke-aplikasi.html[accessed 19 June 2020].

Azra, Azyumardi, Pendidikan Islam: Tradisi Dan Modernisasi Menuju Milenium Baru (Jakarta: Penerbit Kalimah, 2001)

- - - 'Pesantren: Kontinuitas dan Perubahan.' Nurchalish Madjid, BilikBilik Pesantren: Sebuah Potret Perjalanan (Jakarta: Paramadina, 1997)

BWI, 'Digitalisasi Bisa Tingkatkan Antusias Wakaf Pada Kaum Milenial', 2020<https://www.bwi.go.id/4964/2020/04/berita/berita-wakaf/ digitalisasi-bisa-tingkatkan-antusias-wakaf-pada-kaum-milenial/> [accessed 19 June 2020]

- - - 'Global Donor Forum 2012' <https://www.bwi.go.id/759/2012/04/ berita/berita-wakaf/undangan-ikut-serta-dalam-global-donorforum-2012/> [accessed 20 June 2020]

Daulay, Haidar Putra, Pendidikan Islam (Jakarta: Kencana, 2004)

Dhofier, Zamarksyari, Tradisi Pesantren: Studi tentang Pandangan Hidup Kyai, (Jakarta: LP3ES, 2015).

Direktorat Pengembangan Zakat dan Wakaf, Paradigma Baru Wakaf di Indonesia (Jakarta: Dirjen Bimas dan Penyelenggara Haji, 2004)

Fukuyama, Mayumi, 'Society 5.0: Aiming for a New Human-Centered Society', Japan Spotlight, 27.Society 5.0 (2018), 47-50<http://www8. cao.go.jp/cstp/\%0Ahttp://search.ebscohost.com/login.aspx?direct= true $\& \mathrm{db}=\mathrm{b}$ th $\& \mathrm{AN}=108487927 \&$ site $=$ ehost-live $>$

Hasanah, Uswatun, Wakaf Produktif Untuk Kesejahteraan Dalam Perspektif 
Hukum Islam Di Indonesia (Jakarta, 2009)

Hermawan, Wawan, 'Pengembangan Wakaf Di Pusat Pengembangan Wakaf Daarut Tauhiid', Jurnal Pendidikan Agama Islam - Talim, 1.1 (2017), 1-15

Huda, Miftahul, 'Wakaf Dan Kemandirian Pesantren Dari Tebuireng Hingga Gontor', Jurnal Islamica, 7.1 (2012)

Jati, Wasisto Raharjo, 'Memahami Globalisasi Sebagai Evolusi Kapitalisme,'Global \& Strategis, th. 7, No. 2 (2013), 241-57'

Kasdi, Abdurrahman, 'Peran Nadzir Dalam Pengembangan Wakaf', ZISWAF: Jurnal Zakat Dan Wakaf, 1.2 (2014)

Kementerian Agama RI, 'Sistem Informasi Wakaf' <http://siwak.kemenag. go.id/tabel_jumlah_tanah_wakaf.php> [accessed 29 March 2020]

- - - , 'Statistik Pendidikan Islam TP 2014/2015', 2016

Matraji, Abdullah Ubaid, 'Membangkitkan Perwakafan Di Indonesia', Https://Www.Bwi.Go.Id/, 2008 <https://www.bwi.go.id/181/2008/06/ artikel/membangkitkan-perwakafan-di-indonesia/> [accessed 21 June 2020]

Mubarak, A. Zaki, Pendidikan Di Era Revolusi Industri 4.0 Dan Problematika Pendidikan Tinggi (Yogyakarta: Ganding Pustaka, 2018)

Mubarok, Acep Zoni Saeful, Argumen Maslahah Dalam Putusan Pengadilan (Cirebon: Nusa Litera Inspirasi, 2019)

Mubarok, Jaih, Wakaf Produktif (Bandung: Kanwil Departemen Agama Provinsi Jawa Barat, 2009)

Munawwir, Ahmad Warson, Kamus al-Munawwir (Yogyakarta: Unit Pengadaan Buku Buku Ilmiah Ponpes Al-Munawwir, 1984)

Nufzatutsaniah, Nufzatutsaniah, 'Pengaruh Wakaf Produktif Terhadap Peningkatan Ekonomi Pesantren Darunnajah Jakarta', Jimf (Jurnal Ilmiah Manajemen Forkamma), 1.3 (2019), 72-84 <https://doi. org/10.32493/frkm.v1i3.2550>

Paksi, Girindra Mega, Asfi Manzilati, and Marlina Ekawaty, 'Kajian 
Hukum Dan Implementasi Wakaf Harta Bergerak Di Indonesia: Wakaf Uang Dan Saham', Islamiconomic: Jurnal Ekonomi Islam, 9.2 (2018), 173-90 <https://doi.org/10.32678/ijei.v9i2.94>

Ridwan, Murtado, 'Nazhir Profesional Kunci Kesuksean Wakaf Produktif', Jurnal Muqtasid, 3.1 (2012)

Rohmaningtyas, Nurwinsyah, ‘Pengumpulan Wakaf Berbasis Pesantren: Studi Kasus di Pondok Modern Darussalam Gontor dan Pondok Modern Tazakka', Jurnal Ekonomi Syariah, 1.1 (2018)

Siddiq, Achmad, 'Wakaf Produktif Dan Problematikanya Di Dunia Pesantren', Millah, 11.1 (2011), 275-89 <https://doi.org/10.20885/ millah.vol11.iss1.art14>

Suandi, Lim, 'Peluang Dan Tantangan Santri Di Era Digital', Https:// Www.Limsuandi.Com/,2019 <https:/www.limsuandi.com/2019/05/ santrikata-yang-memiliki-makna-dan_2.html> [accessed 20 June 2020]

Sulistiani, Siska Lis, 'Analisis Implementasi Wakaf Wasiat Polis Asuransi Syariah Di Lembaga Wakaf Al-Azhar Jakarta', Ijtihad: Jurnal Wacana Hukum Islam Dan Kemanusiaan, 17.2 (2018), $285<$ https://doi. org/10.18326/ijtihad.v17i2.285-299>

Tim Penulis BWI, Himpunan Peraturan Perundang-Undangan Tentang Wakaf (Jakarta: Badan Wakaf Indfonesia, 2018)

Yuliana, Indah, and Surya Perdana Hadi, 'Model Penerapan Wakaf Saham

Di Indonesia', Jurnal Perspektif Ekonomi Darussalam, 5.September (2019), 227-39

Zarkasyi, Abdullah Syukri, Manajemen Pesantren: Pengalaman Pondok Modern Gontor (Ponorogo: Trimurti Press, 2005)

---, Manajemen Pesantren: Pengalaman Pondok Modern Gontor (Ponorogo: Trimurti Press, 2005) 


\section{Endnotes}

1. Wasisto Raharjo Jati, "Memahami Globalisasi Sebagai Evolusi Kapitalisme," Global \& Strategis, th. 7, No. 2 (2013), 241-57.

2. A. Zaki Mubarak, Pendidikan Di Era Revolusi Industri 4.0 Dan Problematika Pendidikan Tinggi (Yogyakarta: Ganding Pustaka, 2018), h. 11-15.

3. Mayumi Fukuyama, 'Society 5.0: Aiming for a New Human-Centered Society', Japan Spotlight, 27.Society 5.0 (2018), 47-50.

4. A. Zaki Mubarak, Pendidikan,h. 15-16.

5. Wakaf adalah perbuatan hukum wakif untuk memisahkan dan/atau menyerahkan sebagian harta benda miliknya untuk dimanfaatkan selamanya atau untuk jangka waktu tertentu sesuai dengan kepentingannya guna keperluan ibadah dan/atau kesejahteraan umum menurut syariah. Lihat Tim Penulis BWI, Himpunan Peraturan Perundang-undangan tentang Wakaf, (Jakarta: Badan Wakaf Indonesia, 2018), h. 3-26.

6. Muhammad Zubair Abbasi, 'The Classical Islamic Law of Waqf: A Concice Introduction', Arab Law Quarterly, 26.2 (2012), 121-53.

7. Kementerian Agama RI, 'Sistem Informasi Wakaf' <http://siwak.kemenag. go.id/tabel_jumlah_tanah_wakaf.php> [accessed 29 March 2020].

8. Miftahul Huda, 'Wakaf Dan Kemandirian Pesantren Dari Tebuireng Hingga Gontor', Jurnal Islamica, 7.1 (2012), h. 220.

9. Haidar Putra Daulay, Pendidikan Islam (Jakarta: Kencana, 2004), h. 134.

10. BWI, 'Global Donor Forum 2012' <https://www.bwi.go.id/759/2012/04/ berita/berita-wakaf/undangan-ikut-serta-dalam-global-donor-forum-2012/> [accessed 20 June 2020].

11. A. Faishal Haq, Wakaf Kontemporer, dari Teori ke Aplikasi, sumber http:// muslim-shared.blogspot.com/2016/01/wakaf-kontemporer-dari-teori-keaplikasi.html diakses pada tanggal 30 Maret 2020. 
12. Kementerian Agama RI, 'Sistem Informasi Wakaf'.

13. Jaih Mubarok, Wakaf Produktif (Bandung: Kanwil Departemen Agama Provinsi Jawa Barat, 2009), 15.

14. Abdurrahman Kasdi, 'Peran Nadzir Dalam Pengembangan Wakaf', ZISWAF: Jurnal Zakat Dan Wakaf, 1.2 (2014).

15. Abdullah Ubaid Matraji, 'Membangkitkan Perwakafan Di Indonesia', Https://Www.Bwi.Go.Id/, 2008 <https://www.bwi.go.id/181/2008/06/artikel/ membangkitkan-perwakafan-di-indonesia/> [accessed 21 June 2020].

16. Uswatun Hasanah, Wakaf Produktif Untuk Kesejahteraan Dalam Perspektif Hukum Islam Di Indonesia (Jakarta, 2009).

17. Murtado Ridwan, 'Nazhir Profesional Kunci Kesuksean Wakaf Produktif', Jurnal Muqtasid, 3.1 (2012).

18. Abdullah Ubaid Matraji, 'Membangkitkan Perwakafan Di Indonesia.'

19. Achmad Siddiq, 'Wakaf Produktif Dan Problematikanya Di Dunia Pesantren', Millah, 11.1 (2011), 275-89 <https://doi.org/10.20885/millah. vol11.iss1.art14>." author": [\{“dropping-particle":"',,"family":"Siddiq", "gi ven":"Achmad", "non-dropping-particle":",", parse-names":false,"suffix": "'”\}]," container-title":"Millah", "id":"ITEM-1", "issue":"1", "issued":\{“dateparts":[["2011"]]\},"page":"275-289","title":"Wakaf Produktif Dan Problematikanya Di Dunia Pesantren","type":"article-journal","volume ":"11"\},"uris":[“http://www.mendeley.com/documents/?uuid=197327b30374-4831-b174-3d2234c07afd"]\}],"mendeley":\{“formattedCitation":" Ach mad Siddiq, 'Wakaf Produktif Dan Problematikanya Di Dunia Pesantren', $<\mathrm{i}>$ Millah</i>, $11.1(2011$

20. BWI, 'Digitalisasi Bisa Tingkatkan Antusias Wakaf Pada Kaum Milenial', $2020<$ https://www.bwi.go.id/4964/2020/04/berita/berita-wakaf/digitalisasibisa-tingkatkan-antusias-wakaf-pada-kaum-milenial/> [accessed 19 June 2020].

21. Lihat Peraturan BWI No. 1 Tahun 2009 Pasal 1.3. Tim Penulis BWI, Himpunan Peraturan, h. 3-26. 
22. H. M. Athoillah, Hukum Wakaf Benda Bergerak, 1st edn (Sumedang: Alqaprint Jatinangor, 2012), 179-191.

23. Indah Yuliana and Surya Perdana Hadi, 'Model Penerapan Wakaf Saham Di Indonesia', Jurnal Perspektif Ekonomi Darussalam, 5.September (2019), 227-39.

24. Girindra Mega Paksi, Asfi Manzilati, and Marlina Ekawaty, 'Kajian Hukum Dan Implementasi Wakaf Harta Bergerak Di Indonesia: Wakaf Uang Dan Saham', ISLAMICONOMIC: Jurnal Ekonomi Islam, 9.2 (2018), 173-90<Https:// Doi.Org/10.32678/Ijei.V9i2.94>.

25. Siska Lis Sulistiani, 'Analisis Implementasi Wakaf Wasiat Polis Asuransi Syariah Di Lembaga Wakaf Al-Azhar Jakarta', Ijtihad : Jurnal Wacana Hukum Islam Dan Kemanusiaan, 17.2 (2018), 285 <https://doi.org/10.18326/ijtihad. v17i2.285-299>.

26. Raditya Sukmana, "Mengoptimalkan Wakaf di Era 4.0", Tulisan ini adalah rangkuman dari orasi ilmiah penulis dalam pengukuhan guru besar bidang ekonomi Islam pada 22 Juni 2019 di Kampus C Unair, sumber https://www. jawapos.com/opini/02/07/2019/mengoptimalkan-wakaf-di-era-4-0/ diakses pada tanggal 31 Maret 2020

27. Azyumardi Azra, Pendidikan Islam: Tradisi Dan Modernisasi Menuju Milenium Baru (Jakarta: Penerbit Kalimah, 2001), h. 15.

28. Kementerian Agama RI, 'Statistik Pendidikan Islam TP 2014/2015', 2016.

29. Dalam pasal 1 ayat 1 Undang-undang No 41 Tahun 2004 tentang Wakaf, pengertian wakaf adalah perbuatan hukum wakif untuk memisahkan dan/ atau menyerahkan sebagian harta benda miliknya untuk dimanfaatkan selamanya atau untuk jangka waktu tertentu sesuai dengan kepentingannya guna keperluan ibadah dan/atau kesejahteraan umum menurut syariah. Lihat Tim Penulis BWI, Himpunan Peraturan Perundang-undangan tentang Wakaf, (Jakarta: Badan Wakaf Indonesia, 2018), h. 4.

30. Zamarksyari Dhofier, Tradisi Pesantren: Studi tentang Pandangan Hidup Kyai, (Jakarta: LP3ES, 2015), h. 40.

31. Muhammad Zubair Abbasi, "The Classical Islamic Law of Waqf: A Concice 
Introduction", dalam Jurnal Arab Law Quarterly, Vol. 26, No. 2 (2012), pp. 121-153.

32. Sumber Sistem Informasi Wakaf Kementerian Agama RI pada http://siwak. kemenag.go.id/tabel jumlah tanah wakaf.php diakses pada tanggal 29 Maret 2020.

33. Abdullah Syukri Zarkasyi, Manajemen Pesantren: Pengalaman Pondok Modern Gontor (Ponorogo: Trimurti Press, 2005), h. 188, lihat Nurwinsyah Rohmaningtyas, "Pengumpulan Wakaf Berbasis Pesantren: Studi Kasus di Pondok Modern Darussalam Gontor dan Pondok Modern Tazakka." Jurnal Ekonomi Syariah, Vol. 1 No. 1 (2018): 13.

34. Abdullah Syukri Zarkasyi, Manajemen Pesantren: Pengalaman Pondok Modern Gontor (Ponorogo: Trimurti Press, 2005), h. 186. Lihat Achmad Siddiq, "Wakaf Produktif," h. 282.

35. Nufzatutsaniah Nufzatutsaniah, 'Pengaruh Wakaf Produktif Terhadap Peningkatan Ekonomi Pesantren Darunnajah Jakarta', Jimf (Jurnal Ilmiah Manajemen Forkamma), 1.3 (2019), 72-84 <https://doi.org/10.32493/frkm. v1i3.2550>.

36. Achmad Siddiq, "Wakaf Produktif," h. 283.

37. Miftahul Huda, 'Wakaf Dan Kemandirian Pesantren..', h. 225.

38. Wawan Hermawan, 'Pengembangan Wakaf Di Pusat Pengembangan Wakaf Daarut Tauhiid', Jurnal Pendidikan Agama Islam - Ta'im, 1.1 (2017), 1-15.

39. Undang-undang No 41 Tahun 2004 tentang Wakaf, lihat Tim Penulis BWI, Himpunan Peraturan, h. $3-26$.

40. Dalam kitab-kitab fiqh klasik tidak mencantumkan nazhir wakaf sebagai salah satu rukum wakaf, karena wakaf merupakan ibadah tabarru'. Namun karena demi melestarikan manfaat dari hasil harta wakaf, maka keberadaan nazhir sangat dibutuhkan bahkan menempati pada peran sentral. Lihat: Direktorat Pengembangan Zakat dan Wakaf, Paradigma Baru Wakaf di Indonesia (Jakarta: Dirjen Bimas dan Penyelenggara Haji, 2004), 116.

41. Ahmad Warson Munawwir, Kamus al-Munawwir (Yogyakarta: Unit 
Pengadaan Buku Buku Ilmiah Ponpes Al-Munawwir, 1984), h. 1532.

42. Undang-Undang Republik Indonesia Nomor 41 Tahun 2004 Tentang Wakaf, Lihat Pasal 1 Ayat 4 Peraturan Pemerintah Republik Indonesia Nomor 42 Tahun 2006 Tentang Pelaksanaan Undang-Undang Nomor 41 Tahun 2004 Tentang Wakaf, Lihat Pasal 1 Ayat 4 Peraturan Badan Wakaf Indonesia Nomor 1 Tahun 2008 Tentang Prosedur Penyusunan Rekomendasi Terhadap Permohonan Penukaran/Perubahan Status Harta Benda Wakaf, lihat Peraturan Badan Wakaf Indonsia Nomor 03 tahun 2008 tentang Tata Cara Pendaftaran dan Penggantian Nazhir Harta Benda Wakaf Tidak Bergerak Berupa Tanah, dan Peraturan Badan Wakaf Indonsia Nomor 02 Tahun 2012 tentang Perwakilan Badan Wakaf Indonesia. Lihat Tim Penulis BWI, Himpunan Peraturan, h. 3-26.

43. Pasal 11 Undang-undang No.41 Tahun 2004, Lihat Tim Penulis BWI, Himpunan Peraturan,h. 3 - 26.

44. Pasal 9 Undang-undang No 41 Tahun 2004 tentang wakaf, Lihat Tim Penulis BWI, Himpunan Peraturan, h. 3 - 26.

45. Pasal 10 ayat 1 - 3 Undang-undang No 41 Tahun 2004 tentang wakaf, Lihat Tim Penulis BWI, Himpunan Peraturan, 3 - 26.

46. Lihat https://ditpdpontren.kemenag.go.id/ijoppesantren/ diakses pada tanggal 30 Maret 2020

47. Azyumardi Azra, "Pesantren: Kontinuitas dan Perubahan." Nurchalish Madjid, Bilik-Bilik Pesantren: Sebuah Potret Perjalanan(Jakarta: Paramadina, 1997), h. 15.

48. Miftahul Huda, 'Wakaf Dan Kemandirian Pesantren..' , h. 225.

49. UU Pesantren No. 4, ‘Undang-Undang Republik Indonesia Nomor 4 Tahun 2019 Tentang Pesantren', Undang-Undang Republik Indonesia Nomor 4 Tahun 2019, 004078, 2019>.

50. Acep Zoni Saeful Mubarok, Argumen Maslahah Dalam Putusan Pengadilan (Cirebon: Nusa Litera Inspirasi, 2019), h. 111.

51. Tim Penulis BWI, Himpunan Peraturan, 3 - 26. 
52. Lim Suandi, 'Dan Tantangan Santri Di Era Digital', Https://Www.Limsuandi. Com/, 2019Peluang<https://www.limsuandi.com/2019/05/santrikata-yangmemiliki-maknadan_2.html> [accessed 20 June 2020]. 